\title{
A Systematic Review on Advancements in Drinking Water Disinfection Technologies: A Sustainable Development Perspective
}

\author{
Sapna R. Shinde ${ }^{1 *}$, Sayali Apte ${ }^{2}$ \\ ${ }^{1}$ Department of Civil Engineering, Pune, Symbiosis Institute of Technology, Symbiosis International (Deemed University), Pune \\ 2 Department of Civil Engineering, Symbiosis Institute of Technology, Symbiosis International (Deemed University), Pune
}

Received: 15/09/2020

Accepted: 28/10/2020

Published: 20/06/2021

\begin{abstract}
The Sustainable Development Goal 2015-30, which is the blueprint to achieve a better and sustainable future for all includes goal number six, aiming at the provision of clean water and sanitation by 2030 worldwide. But still the rural areas in developing nations are predominantly facing the scarcity of pathogen-free drinking water, which creates an urgent need for research in the area of water disinfection. The paper presents a systematic literature review of the conventional and novel water disinfection techniques supported by a bibliometric analysis based on the data from Scopus and Web of Science data from the year 1980 to 2020 for all the disinfection techniques. The novel and latest water disinfection technology in the literature studied by few researchers are also discussed and it can be concluded that the research related to these latest technologies is fewer and real-life usage is very scanty. The detailed literature review indicates the need for novel, decentralized, low-cost water disinfection technology for providing clean and pathogen-free water to all, overcoming the problems related to access of safe drinking water to rural communities. The paper also identifies the research gaps related to new technologies for water disinfection which needs to addressed in further studies.
\end{abstract}

Keywords: Drinking water disinfection, chlorination, ozonation, ultraviolet light, novel disinfection technology.

\section{Introduction \\ 1.1 Importance and Need of the Research}

The problems related to health and sanitation due to contaminated water being used for drinking purposes is more severe in the rural population (1). The non-availability of treated water mainly in rural areas is due to the high cost of treatment and inaccessibility to the centralized treatment facility. World Health Organization (WHO) estimates the burden of disease caused by unsafe water in collaboration with 14 leading research institutions, in 145 low- and middleincome countries. The study reports that there are a number of deaths in Africa and South-East Asia due to inadequate supply of treated drinking water. According to the report 2,29,316 deaths are noted under the region of Africa in which Angola, Chad, Nigeria, Tanzania are affected due to water borne diseases like diarrhea. (Figure 1). While in the region of South -East Asia- Bangladesh, India, Nepal, Srilanka and Bhutan are affected (2). Whereas, annually around 38 million Indians are affected due to the contamination of drinking water sources in villages resulting in waterborne diseases. Due to Diarrhea alone, the death of children is about 1.6 million. (3). The problem of drinking contaminated water is more apparent in rural sectors, as this area is not connected to the centralized water supply scheme. (4),(5). The lack of drinking water treatment facilities in rural zones is due to the high cost of treatment systems and its heavy maintenance which is not affordable to low-income families (6), (7). The lack of safe and pathogen-free water has led to water-borne diseases (8). The process of disinfection of water can exterminate these disease- causing pathogens. Disinfection is mainly carried out using Chlorination, Ultraviolet Light, and Ozone. Among these three, ultraviolet light and ozone are more costly and not affordable to the low-income groups, furthermore, these both processes offer no residual treatment (9), (10). But chlorination is the only process that maintains a presence of residual effect in water after the treatment also, continuing to disinfect the water during distribution, Therefore chlorination is the worldwide popular method for water disinfestation. (11), (12),(13). But later on, it recognized that, though the chlorine has the advantage to destroy the harmful pathogens which are ruinous to human health; it also has problems related to storage, transport, and handling of chlorine (14), (15), (Addendum and Third). Therefore, the development of safe, decentralized low-cost treatment technology for water disinfection is an urgent need in rural and remote areas to solve health-related issues. Many researchers investigated the advantages of a decentralized system to implement the safe drinking water method with low cost and maintenance (17), (18). The paper presents a detailed study of the current technologies for water disinfection and provides a detailed overview of the status of research and the current technologies in the thrust area. The paper also discusses the gaps in the research and proposes further topics to be researched.

Corresponding author: Sayali Apte, Department of Civil Engineering, Pune, Symbiosis Institute of Technology, Symbiosis International (Deemed University), Pune Corresponding author: Sayali Apte, E-mail: sayali.apte@sitpune.edu.in 


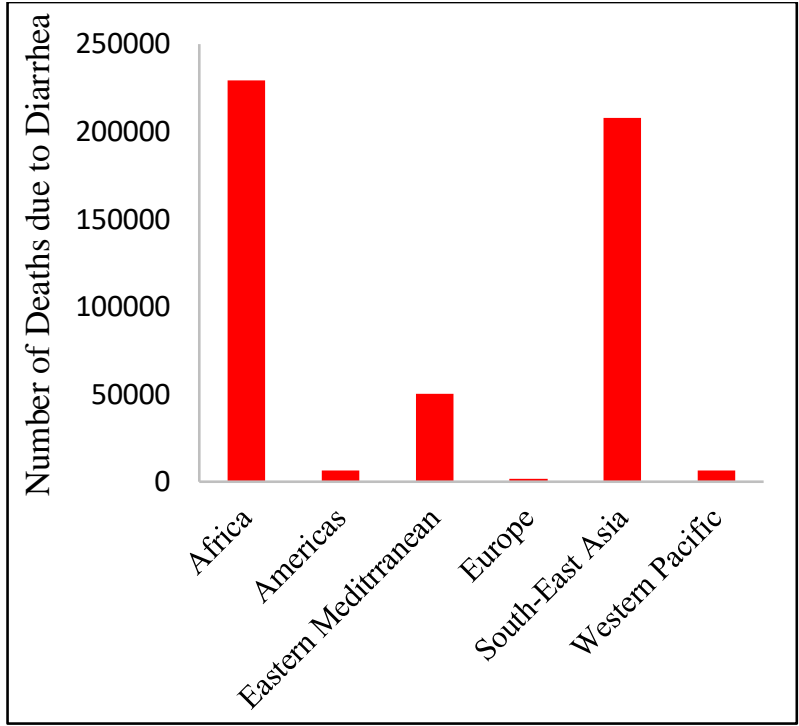

Figure 1: Deaths due to inadequate drinking water in Low and middle-income Regions ('Preventing diarrhea through better water, sanitation, and hygiene', 2014)

\subsection{Importance of the research area}

A lot of issues exist related to drinking water, especially in rural areas. The drinking water treatment and disinfection facilities are gradually increasing with the increase in awareness about safe and pathogen-free water. This increased rate of sanitation is limited to urban areas to a great extent. Rural areas are still facing diminished facilities of drinking water (19).According to the worldindata,(68). the improvement in drinking water facilities till 2015 which was decided under the Millennium Development Goals (MDGs), 2000 inferred that the access to the improved facility of drinking water in rural population is much less than that of urban population as shown in figure 2 and 3 , which is the origin of health issues due to poor facility of treated water and lack of pathogen-free water. Figures 2 and 3 show the percentage of share of urban and rural residents with access to enhanced quality of water sources respectively. The drinking water treatment and disinfection facilities are gradually increasing with the increase in awareness about safe and pathogen-free water as graph compared individually. And if both the graphs compared simultaneously it specifies that even though the increase in the percentage of access to better-quality water in urban zones of the developing countries due to the MDG's 2020, but their respective rural zones of the county have still faced the problem related to access of good quality water. It inferred that the rural zones of both developed and developing countries have very less access to improved water quality as compared to their respective urban zones of countries. Likewise figure 4 shows that in urban areas of Niger and Angola, there is an increase in improved drinking water facilities from the year 1990 to 2015 is up to $100 \%$ and $75.4 \%$ respectively and that of the rural area is $48.6 \%$ and $28.2 \%$ only, which shows that there is the need for a water treatment facility in rural areas. The Millennium Development Goals (MDGs), 2000 that were designed to raise the potable water quality till the year 2015 to every region of the world. Therefore, the values of the percentage of improved water access to urban and rural zones of countries for the year 2015 after completion of the MDG scheme is shown in table 1 to get an idea about the condition of rural zone scenario in the year 2015. While all the huge set of values from the year 1990 to 2015 for each and every country is available on worldindata website as shown in figure 4 for only two countries (Angola and Niger) which has least improvement in the rural region
(69). From table 1 it observed that the percentage of better quality water access in both the urban and village side zones of the developing countries (DRC, Mozambique, Tanzania, Yemen, Afganistan, Angola) is very less than the developed (Canada and Germany) countries even after the Millennium Development Goals (MDGs), 2000. While some of the developing countries like India and Brazil have increased the water quality till 2015 under this goal, but still the percentage increase is more in urban zones only. And hence the Sustainable Development Goal 2015 (20), born at the United Nations Conference in 2012 to achieve better and more sustainable future for all, includes goal number six which is related to the provision of clean water and sanitation till 2030 to every region of the world that thrusts to work in this area.

Moreover, World Health Organization stated in 2017 that out of the total global population, 785 million people are even faced the deficiency of basic drinking-water services, and 2 billion uses contaminated water for drinking purposes which leads to diseases such diarrhoea, cholera, dysentery, typhoid, and polio. Furthermore, half part of the globe's populace will be existing in water-stressed zones by 2025 stated by WHO (21). The inaccessibility of treated water is mainly due to its high cost, maintenance, and centralized treatment facility. Also, there are many drawbacks in the current water treatment system used globally i.e. chlorination. Drawbacks of this system like the problem of chlorine storage and its handling, safety, and transportation explained in detail in the literature. Hence there is a need to engender new technology that will be decentralized, affordable, and accessible to rural zone people along with low maintenance. Therefore, to solve these problems associated with the current water treatment system thrust to do further research in this field. All these reasons illustrate that there is a need for a low-cost decentralized system that will improve the quality of drinking water in rural zones as well.

\section{Literature review \\ 2.1 Categorization of literature}

For the protection of human health from water-borne diseases, it is essential to disinfect the drinking water regularly. Figure 5 shows, the number of past research documents yearwise for decontamination methods of potable water. The graph illustrates the number of documents published, according to the data available on SCOPUS and Web of Science from the year 1980 to 2020 related to drinking Water Treatment for all Disinfection methods. Scopus and Web of science data accessed on $17^{\text {th }}$ May 2020 (70). A total 5366 documents were registered on Scopus and 5265 on Web of Science from the year 1980 to 2020. From this document exploration on Scopus and Web of Science clarify that very less research work piloted related to the treatment of drinking water in the developing countries even though these regions still suffer badly due to untreated water (Figure 6). Figure 6 concluded that very less research efforts performed in developing counties like Nigeria, Tanzania, Kenya, and India than the developed countries like the United States and Canada even though the developing countries are affected most by the water-borne diseases due to the lack of water treatment systems as mentioned above. Therefore, more research has to be carried out and piloted mostly in the rural zones of the developed countries. Based on the past research regarding the decontamination of potable water and how the advancement occurred in these methods along with their pros and cons to search for the new low-cost treatment system from these past research experiences. 


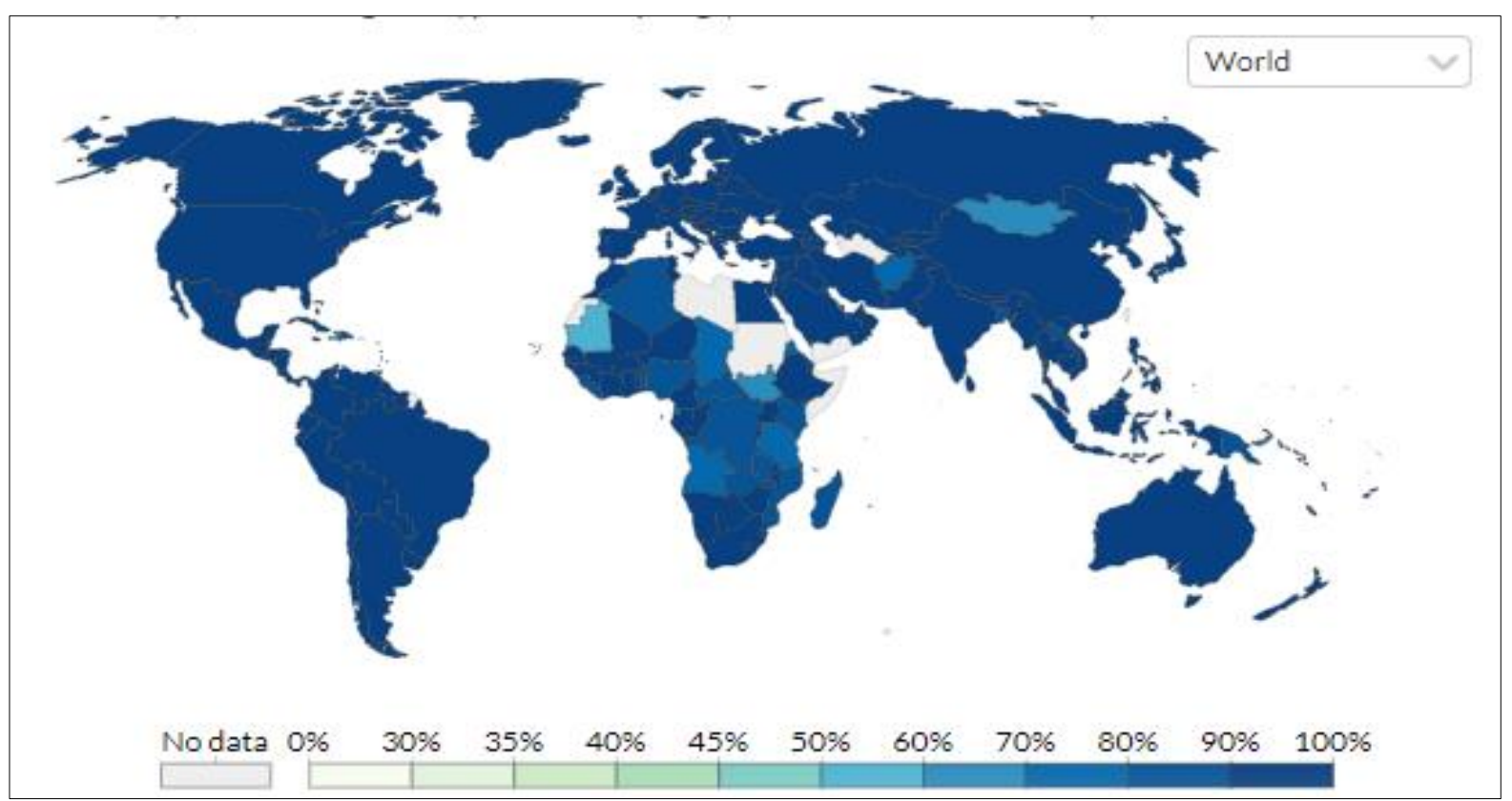

Figure 2: Share of urban population with access to improved water sources, 2015 (https://ourworldindata.org/grapher/urban-population-with-improvedwater)

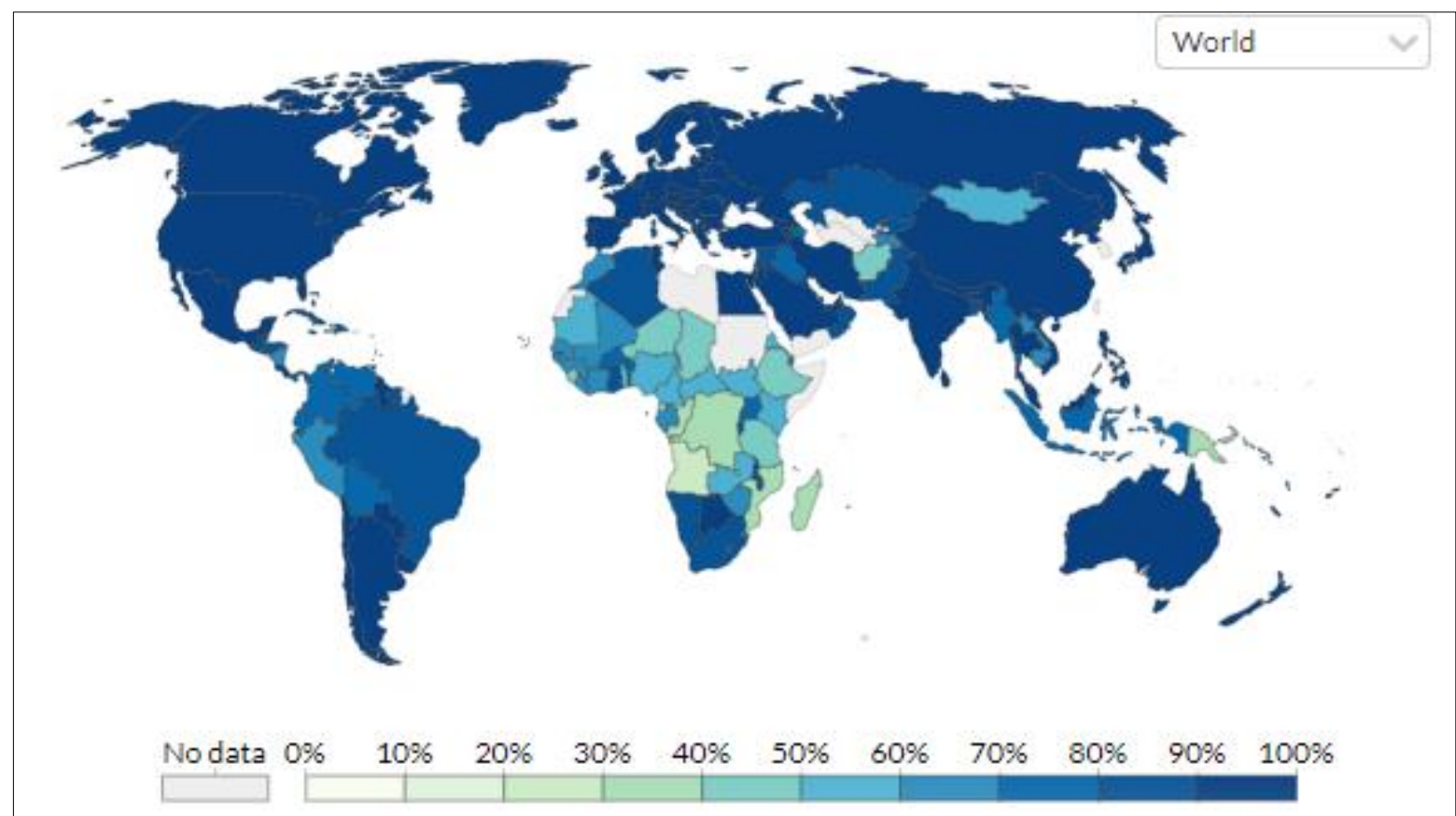

Figure 3: Share of Rural population with access to improved water sources, 2015 (https://ourworldindata.org/grapher/rural-population-withimproved-water)

The literature associated with the most widely used drinking water disinfection methods are as shown in the figure 7. Different physical and chemical treatment methods used for the disinfection of the drinking water. Out of all those Ultraviolet lights, Ozonation and Chlorination was majority widely used for large water treatment plants. Whereas boiling, treatment with excess lime and $\mathrm{KMNO}_{4}$ used rarely and for household purposes. Due to the wide use of these, three processes, the present paper discussed in detail about it and also focuses on the recently upcoming new technology i.e. Electrochlorination. The distribution of the number of documents per year (1980 to 2020) for each of these extensively used methods is shown in figure 7. The ozonation and UV methods are discussed first followed by chlorination. After a thorough review related to disinfection, the literature is categorized as shown in figure

\section{2.2 Literature related to water disinfection using Ozonation and $U V$ disinfection methods}

To disinfect the potable water, Ozonation is one of the methods used, that converted the raw water into clean and potable water by killing pathogens present in it. The number of literature per year on drinking water treatment by Ozonation corresponding to the data available on Scopus and Web of Science are shown in Figure 9. The number of documents found in Scopus and Web of Science is 1683 and 2247 respectively 
(Data from Scopus and Web of Science accessed on $17^{\text {th }}$ May 2020) (71).

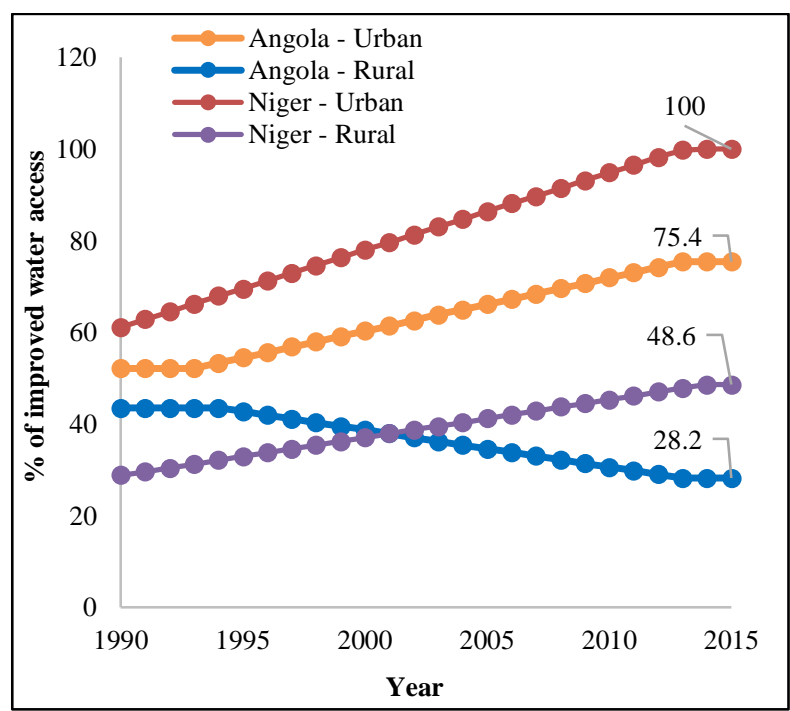

Figure 4: Urban-improved-water-access-vs-Rural-water-access (https://ourworldindata.org/grapher/urban-improved-water-access-vsrural-water-access)

Table 1: Percentage of improved water access in Urban and Rural zones in 2015

(https://ourworldindata.org/grapher/urban-improved-wateraccess-vs-rural-water-access)

\begin{tabular}{|l|l|l|}
\hline Country & $\begin{array}{l}\text { \% of } \\
\text { improved } \\
\text { water access } \\
\text { in the Urban } \\
\text { zone in 2015 }\end{array}$ & $\begin{array}{l}\text { \% of improved } \\
\text { water access in } \\
\text { Rural zone in } \\
\mathbf{2 0 1 5}\end{array}$ \\
\hline $\begin{array}{l}\text { Democratic } \\
\text { Republic of Congo } \\
\text { (DRC) }\end{array}$ & 81.1 & 31.2 \\
\hline Mozambique & 80.6 & 37 \\
\hline Tanzania & 77.2 & 45.5 \\
\hline Yemen & 72 & 46.5 \\
\hline Afganistan & 78.2 & 47 \\
\hline Angola & 75.4 & 28.2 \\
\hline Niger & 100 & 48.6 \\
\hline Nigeria & 80.8 & 57.3 \\
\hline India & 97.1 & 92.6 \\
\hline Brazil & 100 & 87 \\
\hline Canada & 100 & 99 \\
\hline Germany & 100 & 100 \\
\hline
\end{tabular}

(Information from ourworldindata site, accessed on $20^{\text {th }}$ May 2020)

The literature related to ozonation and UV is discussed below. JOHN et al., (1976) commented that the use of ozonation is much less popular than the other treatments mainly due to its excessive insertion and operational costs and mechanical difficulties. Also, it recommended that the ozonation cannot able to maintain the residual effect throughout the distribution system. Beyond all these reasons, one more disadvantage is addressed that is skepticism to the people due to the poisonousness and harmful characteristic of the ozone gas (22). While disinfecting the drinking water by using Ozonation, it required post disinfectant because ozone has no property to exists for a long period as a residual in the distribution outline path. Also, this process is most expensive as compared to
Ultraviolet light and Chlorination treatment (23). Plummer \& Edzwald, 1998, carried out a test for the formation of Disinfection-By-Product (DBP) and analyze how ozonization affects its formation. It shows that the potential formation of Tri halo methane (THM) rose by $10 \%$ to $30 \%$ when preozonation was applied over a non-ozonated sample. Haloacetic acid (HAA) \& Dissolved organic carbon content of algae suspension also shows an increasing trend. Hence it is necessary to either change the method of disinfection or to eliminate algae forming content from the water before oxidation. (24).

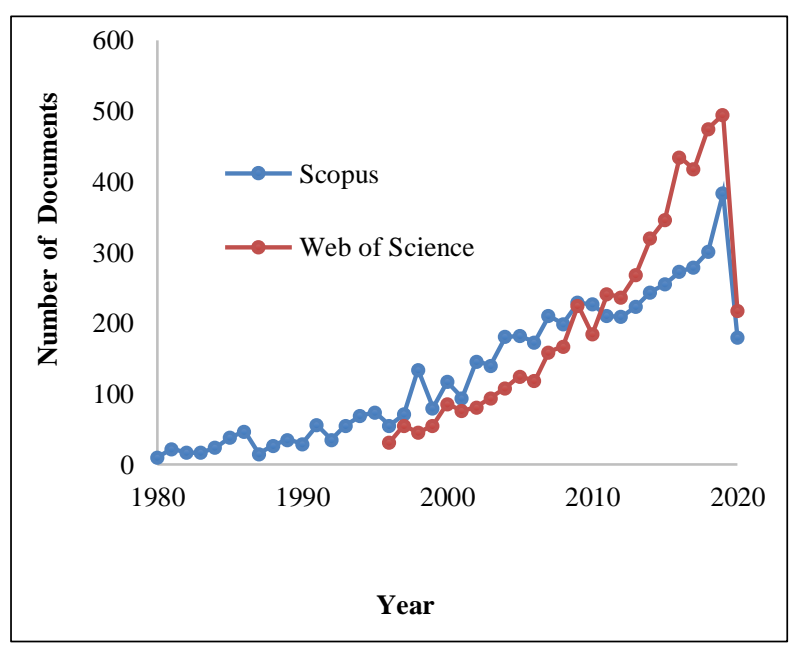

Figure 5: Documents per year on drinking Water Treatment by Disinfection from Scopus and Web of Science

(https://www.scopus.com \& https://www.webofscience.com)

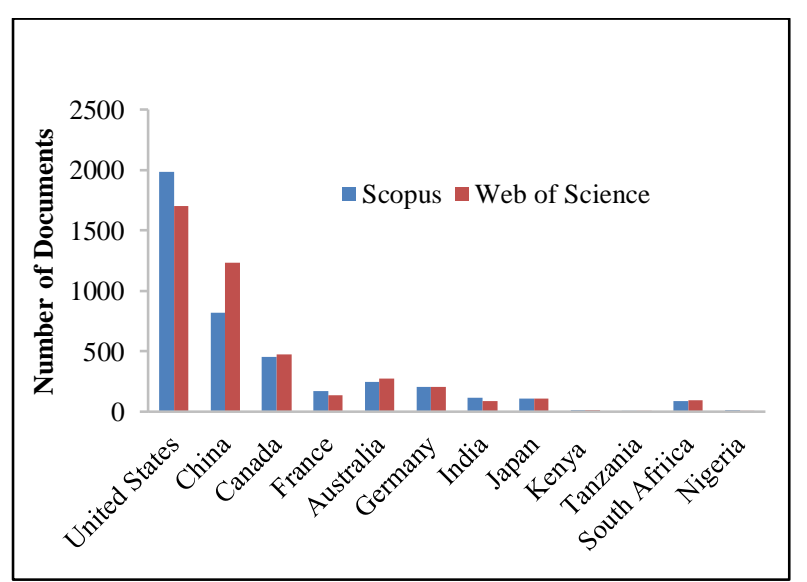

Figure 6: Country-wise number of Documents related to drinking Water Treatment by Disinfection methods from Scopus and Web of Science (https://www.scopus.com \& https://www.webofscience.com)

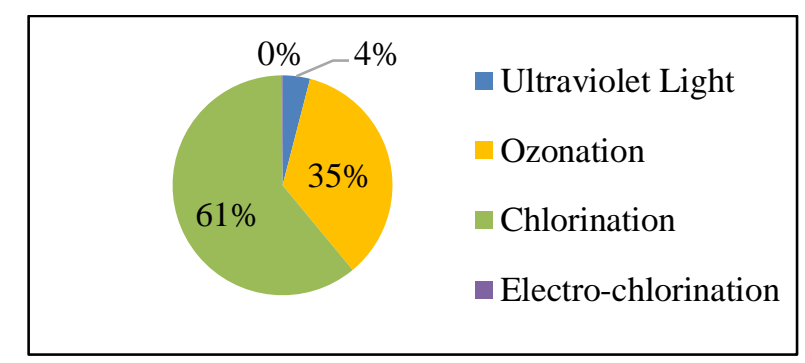

Figure 7: Widely used disinfection methods for treatment of Drinking Water 


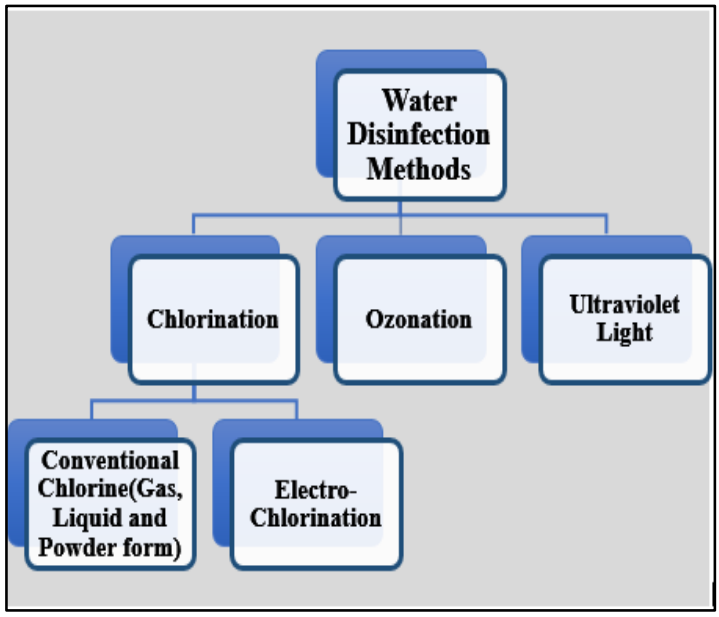

Figure 8: Characterization of literature

Mao et al.,2018, examined the ozone-based electrochemical oxidation process named Electro-peroxone method that is consolidated with customary ozonation through in-situ cathodic hydrogen peroxide $\left(\mathrm{H}_{2} \mathrm{O}_{2}\right)$ creation for oxidative water treatment. This treatment is contrasted with traditional ozonation, which results that the E-peroxone procedure is less effective for decreasing DBP's nevertheless it is useful in the change of $\mathrm{Br}$-to $\mathrm{BrO}_{3}-(25)$.

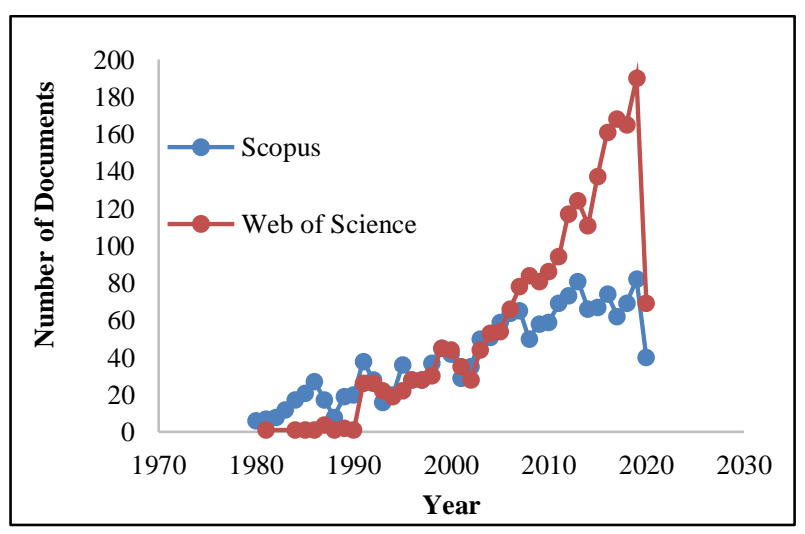

Figure 9: Documents per year on drinking Water Treatment by Ozonation from Scopus and Web of Science

(https://www.scopus.com) and (https://www.webofscience.com)

During purification of water by ozone, Van der Merwe et al., 2012, represents oxidation of non-Cr (VI) comprising substances dangled in $\mathrm{H}_{2} \mathrm{O}$. South Africa grips the mainstream of worldwide chromium ore sources, hence this paper more over-emphasis on South African Context. Results specify that in the course of treatment of water by means of ozone with non$\mathrm{Cr}$ (VI) Cr-containing constituents in suspension can created $\mathrm{Cr}$ (VI) in situ. $\mathrm{pH}$ also an influencing formation of $\mathrm{Cr}$ (VI). This paper shows the significance of eliminating suspended particulate from water at $\mathrm{pH}$ pertinent to drinkable water former to ozonation as $\mathrm{Cr}$ (III) compounds are hastened out (26). For a water treatment plant on Kinmen Island, Chein et al., 2018, dealt with rapid-sand-filtration sewage. There genuine cyanobacterial flushes that arisen, was utilized to assess the DOC-and DBP-expulsion proficiency of ozonation and biofiltration. For analysis, a minor dimension water supply scheme for $24 \mathrm{hr}$ is developed and tests were conducted. Trihalomethanes (THMs), haloacetic acids (HAAs), haloacetonitriles (HANs), and trichloronitromethane (TCNM) were examined. Ozonation alone produced unfavorable impacts by advancing THM, HAA, and TCNM. Ozonation and
BAC filtration together yield well DOC expulsion (51\%) over Biologically Activated-carbon filtration (BAC) alone (41\%). Taking the expense of ozonation into thought, for a minor dimension water supply scheme for treating the high cyanobacterial natural issue in water, BAC biofiltration alone could be a proficient, cost-effective adoption for declining DBP originators (27). To decide the consumption and impact of periodic changes in water handling parameters, Hua et al., 2006, collected water samples from main opinions in 2 watercourses of the model plant arrangement. This research paper demonstrates that ozone action is profoundly powerful in exhausting carbamazepine, caffeine, cotinine, and atrazine however as of now, not very many Canadian DWTPs join ozonation into customary treatment, which recommends that individual contact to these mixes through drinking water utilization might be a problem in pretentious societies.(10). Ozone is broadly used to treat potable water because of its solid biocidal oxidizing properties. Two kinds of water grid were expected for this examination. Out of one is water containing humic corrosive, which is industrially accessible. And another one is water from the Han River. This examination detailed that hydroxyl radicals started by the ozone chain response were essentially successfully operative (28). Schlichter et al., 2004, explained a compound process, including ozonation and film purification, trailed by enacted carbon filtration, was examined in a trial for potable water creation from stream water. The primary accentuation of this examination fixated on tests to decide the impact of ozone on the filtration and fouling conduct of porcelain microfiltration and ultrafiltration films. Ultrafiltration of the water with the expansion of ozone demonstrated which produces $99 \%$, can be accomplished with no diminishing film porousness while eliminating the requirement for film backflushing. To evaluate the treatment procedure and the water characteristics produced, the most significant synthetic and bacteriological logical constraints were inspected in the feed stream water and in the processed water after every treatment stage and were then examined. Microbiological investigation indicated that coliform microscopic organisms, E-coli, Pseudomonas aeruginosa, Clostridia, and fecal streptococci, which were in some cases present in the waterway, could be disposed of entirely (29). When bromide ion is present in water, ozone has the property to convert a certain amount of the bromides to bromate according to the reaction surroundings of the treatment process. These bromates can also be mixed into the potable water which acts as a purifier. Ozone has established to be a very valued tool for several global potable water services to meet their corresponding water characteristic goals and Fairfax Water is no exception (30).

Ultraviolet light is another the drinking water disinfection method in which the pathogens and bacteria present in water killed with the help of ultraviolet light. Figure 10 shows the documents per year on drinking water treatment by Ultraviolet light from data available on Scopus and Web of Science. Associated with the Ultraviolet light disinfection, a total of 194 documents were filed on Scopus and 178 are from the Web of Science. In the section below the literature related to the ultraviolet light is outlined. The ultra-violet light system has several problems. One is short-circuiting among the UV compartments, biofouling of the lamp surface which reduces the effective intensity of the UV treatment after a certain period of time. Practicably to decide the UV dose constantly and reliably is the furthermost significant problem in the practice of $\mathrm{UV}$. While the cost of the UV treatment is comparatively higher than that of the Chlorination treatment (23). Wei Liu et al., (2006) compared the UV irradiation with chlorine disinfection for four different types of water samples. The observations of 
the study commented that the UV irradiation usually produced statistically substantial rises for the development of DBP's like chloroform, DCAA (Dichloroacetic Acid), TCAA (Trichloroacetic Acid) and $\mathrm{CNCl}$ (cyanogen chloride) (31). During the ultraviolet light (UV) disinfection, the enormous amount of nitrite $\left(\mathrm{NO}_{2}^{-}\right)$produced from nitrate $\left(\mathrm{NO}_{3}{ }^{-}\right)$present in untreated water and that causes serious human diseases. Therefore Ning Lu et al., (2009) explored various experiments, to found out the variation in the formation of nitrite from nitrate due to the application of ultraviolet light to disinfect the drinking water. In this analysis, the creation of $\mathrm{NO}_{2}^{-}$from $\mathrm{NO}_{3}{ }^{-}$ was investigated under the action of a low-pressure ultraviolet (LPUV) lamp at $253.9 \mathrm{~nm}$ with variation in initial $\mathrm{NO}_{3}{ }^{-}$ concentration, solution $\mathrm{pH}(6.2-9.5)$, and hydrogen peroxide $\left(\mathrm{H}_{2} \mathrm{O}_{2}\right)$ dose (0-25mg L21) and the effect of titanium dioxide $\left(\mathrm{TiO}_{2}\right)$. The outcomes of these experiments exhibited that the establishment of $\mathrm{NO}_{2}{ }^{-}$was fostered at a larger preliminary $\mathrm{NO}_{3}{ }^{-}$ concentration and an exalted $\mathrm{pH}$. And the major decrease in the formation of $\mathrm{NO}_{2}^{-}$was observed after the addition of $\mathrm{H}_{2} \mathrm{O}_{2}$ in the presence of the titanium dioxide.(32).

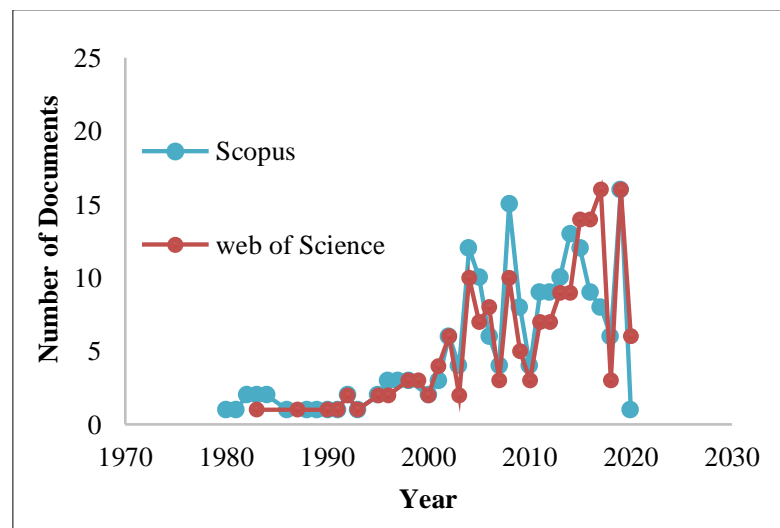

Figure 10: Documents per year on drinking Water Treatment by Ultraviolet Light from Scopus and Web of Science

(https://www.scopus.com) and (https://www.webofscience.com)

Yonkyu Choi (2010) assess the outcomes of UV action on potable water characteristic in delivery schemes on the basis of the potential of biological re-growth, chlorine demand, and DBPs formation. From his findings, he concluded DOM (Dissolved Organic Matter) characteristics were not considerably affected by the UV disinfection. Whereas the UV light method raised the early quick chlorine intake inside the clear well, however, it may not influence altogether the moderate chlorine deterioration percentage in the supply framework. As a result, Chlorine utilization raised after UV illumination that can provoke an increment of DPBs formation (33). Between 1975 and 2006 US Environmental Protection Agency published, 18 National Environmental Primary water regulations between 1975 to 2006 . According to it for more regulations on water, the more use of advanced technologies such as microfiltration/ultrafiltration(MF /UF) membranes, ozone, ultraviolet light (UV) required. But these advanced technologies consume more energy than the conventional treatments and ultimately increases the cost of treatment and price of water (American Water Works 2012). Lin deng et al., (2014) compared the results of the combined UV/Chlorine (low-pressure ultraviolet (LPUV)) and free chlorination on the formation of trichloronitromethane (TCNM) byproduct. From the investigations, it detected that the united UV/chlorine treatment can rise TCNM establishment by $2-15$ fold associated with free chlorination merely under disinfection (35).

The potential of DBP formation is approximately more in Ultraviolet light disinfection than in chlorine photolysis (36).
Mcdonald et al.,2000, illustrate the various Ultraviolet Light Technologies. In this paper, the features and effectiveness of these distinct technical methodologies are defined and contrasted. The study concludes that the pulsed UV systems seem to have several benefits over (continuous wave) $\mathrm{CW}$ systems, involving unpredictability and mobility, spectrum shift, etc (37).

\subsection{Inference from literature related to the water disinfection treatments}

From the literature, it inferred that the ozonation and ultraviolet light convert some of the bromides in water to bromate, which is harmful to human health (30). The potential of DBP formation is approximately more in Ultraviolet light disinfection than in chlorination (36) While the ozonation process also produces DBP's which affects human health (24). Due to the less solubility of the ozone than the chlorine in water, it is not able to reach the maximum disinfectant concentration as in the chlorination. The production of ozone is greatly challenging than that of the chlorine and hence it is more expensive (9).On the other hand, for the treatment by ultraviolet light, the water should not be turbid and cloudy. Because the presence of such particles in the water will hinder the ability of the UV radiation to penetrate it and destroy the microorganism within which needs water filtration prior to the purification which adds expense to the procedure (29) Moreover both the processes ozonation and ultraviolet light offer no residual effect which requires an additional chemical process which automatically increases the cost of treatment (10). While that of the chlorination process provides a residual effect which is the major advantage of the chlorination treatment (12),(13).The ultra-violet light system has several problems like short-circuiting through the UV chambers, biofouling of the lamp surface, and high cost of UV treatment (23). Chlorination is cheaper than ozonation and ultraviolet processes and hence it is used worldwide than these two methods. (38),(39),(23).

\subsection{Literatures related to the chlorination and inference from that literature related to chlorination process}

Figure 11 illustrates the number of documents per year related to drinking Water Treatment using chlorination from 1980 to 2020. Overall, 2929 and 2589 documents were recorded from Scopus and Web of Science data respectively. Figure 12 indicates the Country wise variation of number of Documents related to drinking Water Treatment by Chlorination from Scopus and Web of Science. From this graph also, it observed that there is a need to do more investigation on advancement in water treatment systems in developing countries. In 1890, scientists had discovered that chlorine served as an appropriate defense against waterborne microorganisms. Though, this process used in developed and developing countries widely, it observed that yet the chlorine has the advantage to destroy the harmful pathogens which are ruinous to human health; it also has bad effects if the amount of residual chlorine increased beyond the standard limit. Disadvantages of using powder and gaseous form of chlorine: The use of gas and liquid chlorination has critical issues of storage and safety. Chlorine gas is a strong oxidizer and considered toxic (40) Hence, during the planning of a water treatment plant, special storage, and handling considerations are taken for chlorine gas (41). Skilled supervision is necessary for the handling of chlorine. A written emergency plan should be ready and workers should be experts in any of the procedures that require their involvement (15),(Addendum \& Third, 2017, WHO). Drinking-water systems using chlorine for disinfection should monitor continuously for free chlorine residual at least 
once per day before the water pass in the distribution system after the minimum contact time and periodically at representative points in the distribution system. Since the hazardous effects of chlorination affect human health due to the extra amount of residual chlorine beyond the standard limit (42). Also, in the course of recent years, there have been many mishaps including chlorine across the country, harming thousands. Some mishaps due to chlorine found in literature as follows: The Chlorine gas leak at Jamshedpur, India May 31, 2008. Around 150 to 200 individuals had been hospitalized (72).14 July 2010, chlorine spill rate was accounted for at Haji Bunder risky freight distribution center in the Mumbai Port Trust (MPT), Sewri, influencing more than 120 individuals in the area (43). Individuals experience the ill effects of chlorine presentation in a hole at Ephrata's water plant, October 15, 2018-Chlorine spilled from a 150-pound chamber with people in general works office around 7:30 a.m. at the plant located at 321 Church Ave. as per Ephrata police Chief Bill Harvey (73).Falakh \& Setiani, 2018, presumed that among 22 potential perils in WTP, Chlorine and fire spillage gets the most noteworthy estimation of risk since its effect undermines numerous things, for example, mechanical calamities that could jeopardize human life and the earth (44). One major disadvantage of the chlorination treatment originate during literature analysis is the formation of Disinfection-By-Product after treating the drinking water which affects human health due to the consumption of such type of treated water for a long duration. Hrudey, 2009, focused on the DBP's produced after the biochemical treatment of drinking water. He studied the treatment process and discussed that human health has risks due to the consumption of such chemically treated water which produces DBP's after its treatment (45). The main disadvantage of chemical disinfection is Disinfection By-Product formation after the treatment which affects human health badly (46), (47), (48), (49).

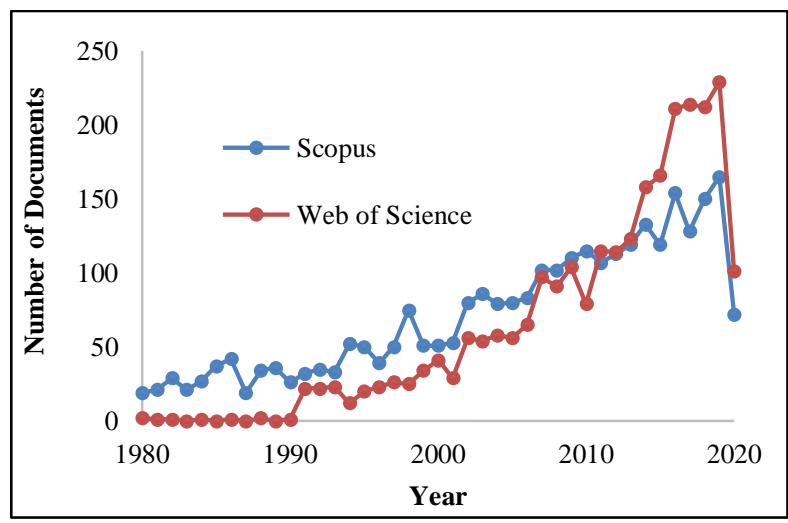

Figure 11: Documents per year on drinking Water Treatment by Chlorination from Scopus and Web of Science

(https://www.scopus.com) and (https://www.webofscience.com)

There are many drawbacks in chlorination. Drawbacks of this system, like the problem of chlorine storage and its handling, safety, and transportation, DBPs formation. Hence there is a need to engender new technology that will be decentralized, affordable, and accessible to rural zone people along with low maintenance. Therefore, to solve these problems associated with the current water treatment system thrust to do further research in this field.

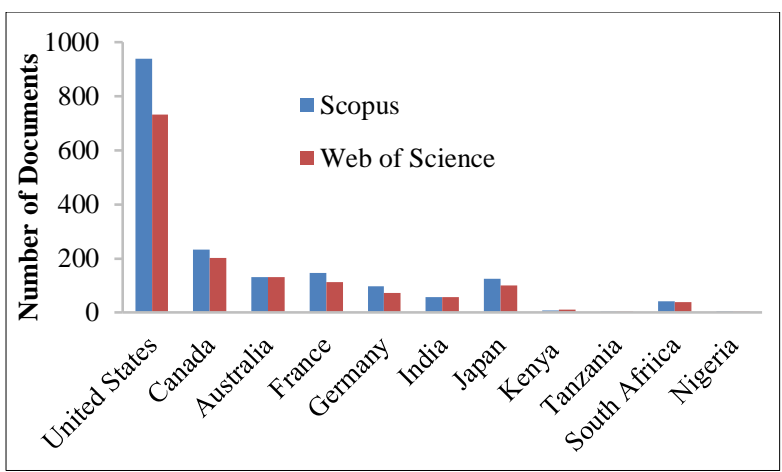

Figure 12: Country-wise number of Documents related to drinking Water Treatment by Chlorination from Scopus and Web of Science (https://www.scopus.com) and (https://www.webofscience.com)

\subsection{Literature to search for novel technology}

The novel technologies for disinfection of the drinking water that has been emerged in recent years are DeepUltraviolet light-emitting diodes technology (DUV-LEDs) with a water waveguide (WW) (50), Inductively Coupled Plasma System (51), Nanobubble Technologies (52), Bioanalytical approach (53), Ultraviolet light-emitting diode reactors (UV-LEDs) (54) and Electro-Chlorination (55). Takahiro Matsumo et al.,2019 exhibited the instant decontamination of polluted water by combining the pointsource features of Deep-Ultraviolet light-emitting diodes (DUV-LEDs) with a water waveguide (WW) that was successfully demonstrated. But this technology required a significant amount of electric power and hence further investigations are going on with a combination of the photovoltaic (PV) cell (50). Newly emerged technology that is Ultraviolet light-emitting diodes (UV-LEDs) is poorly characterized in full-scale drinking water treatment systems and hence Peter Jarvis et al.,2019 investigated UV-LED reactor that is world's first full-scale UV-LED reactor for cleansing of pathogenic microbes from drinking water (54). While Electrolysis process performed well than chlorination in decreasing bacteria and opportunistic pathogens along with regulation on the formation of by-products (56). Consequently, to overcome tackles of chlorination additional literature is assessed and it appears that the new technology Electrochlorination that can be used to treat the drinking water: Eugene \& Suffet, 2002, present a new technology that reduces the shortcomings of the chlorination process. Due to the chlorination process, bromide formation in water takes place and thus producing by-product i.e. Trihalomethanes (THMS) affecting human health. In this paper, new technology is researched that oxidizes Bromide by electrolysis (electrochlorination) to bromine, and afterward, the bromine evidently volatilized. Due to the reduction in bromide, there is a reduction in by-product formation which does not affect human health (57). Jung et al., 2007, explored the outcome of the electro chlorination process on DBP formation. The study concluded that with rising electric conductivity the establishment of miscellaneous oxidants is boosted, nevertheless restricted at conductivities more noteworthy than $0.6 \mathrm{mS} / \mathrm{cm}$. Also, the development and decrease of DBPs were concentrated by observing the grouping of halo acetic acids (HAAs) during the procedure. This study concludes that the electro chlorination process reduces the formation of DBP's (58). Alexander Kraft, (2008) reviewed the electrochemical water disinfection and he concludes that due to the unfamiliarity of the process it was rarely used but this process is a convenient and highly efficient way for the production of germ-free water. 
Djamel et al., 2010, compared the chlorination method with the electro disinfection process. From many laboratory experiments, it was concluded that the electro decontamination procedure is more effective than the chlorination process. In Electro-disinfection (ED) treatment no transportation, storage, and dosage prescription, for decontaminators are needed. Hence this ED treatment's advantages are evident as related to the other disinfection approaches (59). Li et al., 2011, compared the electrochemical method with the ozonation and chlorination method with 4 varieties of pointer microbes. When experiments were carried out at their optimal conditions, the results conclude that the order of availability of disinfection is electro-chlorination followed by ozonation and then chlorination. Whereas inactivation of BST and Bacillus was greatly time-consuming than E. coli and S. aureus in ozonation and chlorination than the electro chlorination (9). For deactivation of microbial bacteria in drinkable water (60) compared the electrochemical disinfection with chlorination. $\mathrm{He}$ concluded that the electrochemical disinfection was 3 whiles additional operative in counteracting B subtilis, although at the minimal quantities of chlorides than the chlorination process.

\subsection{Inference from literature related to novel technology}

These above research papers inferred that the DeepUltraviolet light-emitting diodes technology (DUV-LEDs) and Ultraviolet light-emitting diode reactor (UV-LEDs) technologies required more energy and cost for its experimentation and implementation. While the results of the Inductive Coupled Plasma System proposed that there is a need for further work to make the process serviceable by increasing the applied frequency for the elimination of pathogenic bacteria. Also, Nanobubble technology is short-lived and further investigations have to be performed to exist as a longterm treatment process. Also due to the unfamiliarity of the electro-chlorination process, it was rarely used but this process is a convenient and highly efficient way for the production of germ-free water (61). While electrochemical disinfection was three times more effective in neutralizing Bacillus Subtitles, seven at the low levels of chlorides than the chlorination process (60). Also, the inactivation of disease-causing pathogens is slower in the ozonation and chlorination process than the electro-chlorination process (9). Bromide which is formed during ozonation and chlorination is apparently oxidized in the electro-chlorination process (57). Jung et al., 2007, concluded that the Electro-chlorination process reduces the formation of DBP's. Finally, it was established that the electro decontamination practice is more operative than the chlorination process (14), (58),(48). Furthermore, it determined that electro-chlorination is the best alternative to the chlorination process. It is noticed that Electro-chlorination is the technology used to disinfect the drinking water in which inline production of chlorine resolves the problem of storage, transport, and safety issues to conquer the drawbacks in the chlorination process with the provision of residual effect (62). Correspondingly as discussed above that the Deep-Ultraviolet light-emitting diodes technology (DUV-LEDs) and Ultraviolet light-emitting diode reactor (UV-LEDs) required more power and also UV light treatment is much costly than the chemical processes, hence the new developments related to these technologies are few. And experimental inventions are observed to be performed mainly in developed countries like the United States and Japan who can afford those technologies expenditure. Hence in this paper, from all these new technologies, low cost, low maintenance, simple, sustainable treatment system i.e. Electro-chlorination is discussed further which can be used in developing countries as well.

\subsection{Literature on Electro-chlorination}

As explored on Scopus and web of science, related to the electro-chlorination treatment for drinking water it appears that very less work piloted in accordance with this technology as shown in Figures 13 \& 14. From Figure 13, it comprehended that research associated with the Electro-chlorination in drinking water has started from the year 2004 but no documents were filed from the year 2006 to 2012 associated with the SCOPUS data. According to the SCOPUS statistics, in 2004, 2005, 2013 and 2019 one paper have published each year while in 2017 and 2018 two papers in each year were documented i.e. total only 8 documents were reported. Whereas according to the Web of Science data (Figure 13) total of 7 documents were registered, from which each paper in the year 2002, 2008, 2009 , 2013, and 2017 has published while in 2018, two papers were documented. Out of the total of 8 documents from SCOPUS data, 4 documents were filed from India (Figure 14) but these papers have explained only about the lab-scale models, no pilot station in real contexts is exists. While in a developed country like Germany, it publishes two documents that are related to the pilot stations which exist in a real scenario. And the undeveloped countries (Nigeria, Tanzania, Kenya, etc.) which endure waterborne diseases due to untreated water has not a single record for new technologies like Electro-chlorination. Hence from Figure 14, it can be extrapolated that, the electrochlorination in drinking water treatment has a wide scope to do further research, as less work piloted in developing countries like Nigeria, Tanzania, Kenya, South Africa, and India. Though few researchers concluded the benefits of the electrochlorination process theoretically, very few pilot systems are evolved till date in real scenarios to disinfect water in developing countries. (Scopus and Web of science data accessed on $17^{\text {th }}$ May 2020).

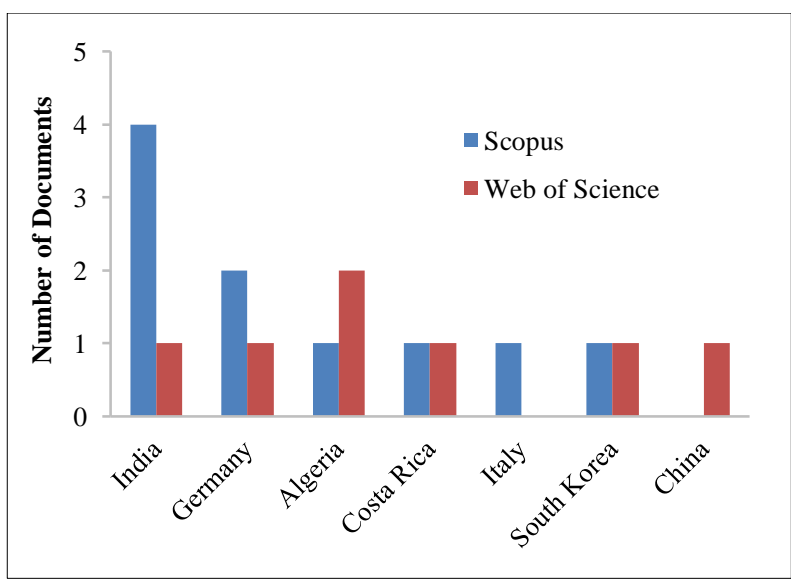

Figure 14: Countriwise number of Documents related to drinking Water Treatment by Electro-Chlorination from Scopus and Web of Science (https://www.scopus.com) and (https://www.webofscience.com)

Khelifa et al., 2004, explored the outcome of the proportion of anode and cathode surface areas $(\mathrm{Sa} / \mathrm{Sc})$, the intra-electrode gap, type of cathode (graphite, stainless steel, nickel, titanium) and anode (graphite, platinum-coated titanium (Ti/Pt), ruthenium oxide-coated titanium $(\mathrm{Ti} / \mathrm{RuO} 2))$, on the generation of active chlorine from aqueous sodium chloride solution. The experiments result for ruthenium-coated titanium anode $(\mathrm{Sa}=24$ $\mathrm{cm} 2$ ), titanium cathode, $\mathrm{Sa} / \mathrm{Sc}=1.33$, with an inter-electrode gap of $0.5 \mathrm{~cm}$, current density of $35 \mathrm{~A} / \mathrm{dm} 2$ under the temperature of $200 \mathrm{C}$ with $3 \mathrm{M} \mathrm{NaCl}$ concentration for 2 hour electrolysis time, the maximum concentration of active chlorine produced is $65.67 \mathrm{~g} / \mathrm{L}$. 


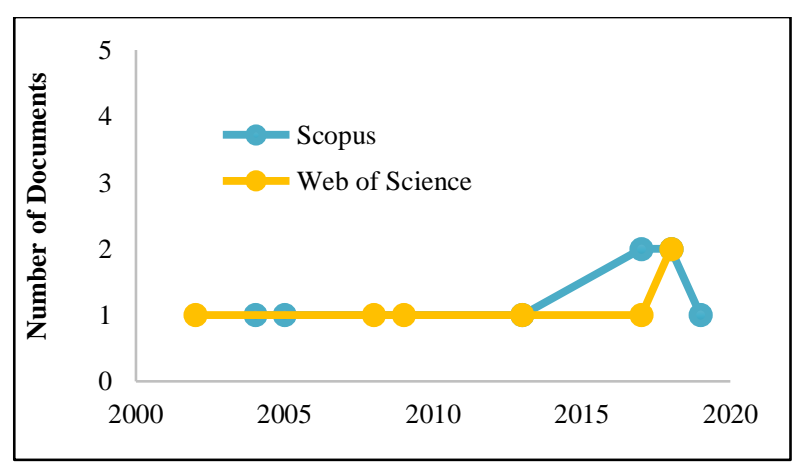

Figure 13: Documents per year on drinking Water Treatment by Electro-Chlorination from Scopus and Web of Science (https://www.scopus.com) and (https://www.webofscience.com)

From the experiment, it concludes that the significant yield of active chlorine was strongly bound to the characteristic of the anode while the character of the cathode has a slight impact on the electro-chlorination process under their operational circumstances. Though the experiment concluded that the ruthenium-coated titanium anode shows best results out of all other anodes, but it displayed a poor resistance towards oxidation after some time which resulting in crumbling. The researcher commented that it is ongoing work so results may change as more work is done associate with it. In this experimentation investigator didn't change the type of electrolyte, results obtained are only using $\mathrm{NaCl}$ electrolyte (63). Nasser Abu Ghalwa et al., 2012, used $\mathrm{C} / \mathrm{PbO} 2$ and $\mathrm{Pb} / \mathrm{PbO} 2$ modified electrodes as an anode. In this study, experiments were carried out with a change in current density, $\mathrm{pH}$, potential, temperature, the concentration of $\mathrm{NaCl}$ solution, electrolysis time, inter-electrode gap, and electrolyte type to check the effect on a generation of active chlorine $(\mathrm{NaOCl})$. Results show that c/pbO2 electrode is more efficient in generating $\mathrm{NaOCl}$. While $\mathrm{NaCl}$ electrolyte is more efficient than other electrolytes. But researchers not performed the experiments with the change in electrode, $\mathrm{Sa} / \mathrm{Sc}$ ratio, size, and shape of the electrode (64). Choi et al., 2013, examine the substantial design and working constraints influencing current effectiveness and power utilization in an electro-chlorination system. $\mathrm{IrO}_{2}$ terminals (utilized as an anode), $\mathrm{NaCl}$ concentration, current density, a partition, and temperature control were chosen as the design and working parameters in the two-cathode bunch framework. This research concluded that the most significant design and working parameter influencing the current density and power utilization was $\mathrm{NaCl}$ concentration, consequently, $\mathrm{NaCl}$ concentration ought to be contemplated first. At that point, deciding the anode type, current density, and the existence of a divider would turn out to be extensively significant when electro-chlorination is worked at a low $\mathrm{NaCl}$ concentration $(1000 \mathrm{mg} / \mathrm{L})$ because the sort of anode, current thickness, and the occurrence of a partition impressively influenced current proficiency and power utilization for chlorine production at a little $\mathrm{NaCl}$ fixation (1000 $\mathrm{mg} / \mathrm{L})$. Whereas in comparison, the type of anode became inconsequential at an extreme $\mathrm{NaCl}$ concentration $(>35,000$ $\mathrm{mg} / \mathrm{L}$ ), However Choi et al., carried out experimentation, only related to the effect of the anode on current density and power consumption. No investigations regarding the change in electrolyte, inter-electrode gap (65).

Saha \& Gupta, 2017, designed an electro-chlorination reactor using six cylindrical shape graphite anodes and stainless-steel cathodes. $\mathrm{NaCl}$ electrolyte having a concentration of 0.01 and $0.5 \mathrm{M}$ was used. By varying current densities, electrolysis time, chloride concentration, and $\mathrm{pH}$ number of tests were analyzed to determine their effect on chlorine generation with a constant value of chloride dilution of $8.5 \mathrm{mg} / \mathrm{l}$ (tap water). Results show that, chloride concentration reductions with growth in current density. Production of inorganic by-products increases with an increase in current density. An enhanced active chlorine strength of 0.75 $\mathrm{mg} / \mathrm{l}$ can be accomplished at an electrolysis time of $30 \mathrm{~min}$. With increasing chloride concentration, active chlorine production rate also increases. From experiments, it discovered that the available chlorine and total chlorine generation enhanced in trivial alkaline $\mathrm{pH}$. Inexpensive Graphite electrode reduces the energy utilization of the reactor. In this research experiment were carried out using only one single electrolyte, no other type of electrolyte was investigated. And though the study concluded that the graphite electrode reduces the energy consumption of the reactor its rate of corrosion is higher (66). Riyant et al., 2018, performed the decontamination of coliform and $\mathrm{E}$. Coli in $\mathrm{H}_{2} \mathrm{O}$ by means of electrolysis with the Carbon electrode as cathode and anode electrodes. The electrolysis technique was incorporated with alternatives of time $(30,60$, $90,120$ minutes at a voltage of $5 \mathrm{~V})$ and voltage $(5,10,15,20$ $\mathrm{V}$ for 30 minutes) to decide the influence of the decontamination of microbes. The outcomes presented the amount of coliform and E. coli in the water previously and afterward, the electrolysis was 190 and $22 \mathrm{MPN} / 100 \mathrm{ml}$, correspondingly. Nevertheless, according to the specifications, the quality of drinking water No. 492/Menkes/Per/IV/2010 does not involve any coliform and E. Coli. Research accomplish that the electrolysis with the change in time interval and capability can diminish the quantity of coliforms and $\mathrm{E}$. Coli but was not in agreement by norms. But Decontamination of bacteria electrolyzes successfully kills coliform and E. coli microorganisms in freshwater by means of carbon electrodes with potential over 15 V i.e. 0 (zero) MPN/100 mL (55).

\section{Summary and conclusions}

The paper discusses the present scenario of drinking water disinfection worldwide and provides a systematic review of literature on conventional and novel drinking water disinfection techniques. The inaccessibility of pathogen-free water in remote rural areas in developing countries is mainly due to centralized treatment facilities with limited capacity and high cost of treatment making the treated water inaccessible and not affordable to remotely located low-income families. The unavailability of the clean potable water, even after the completion of the Millennium Development Goal 2000 which was designed for provision of clean water and sanitation till 2015 to everyone and then the Sustainable Development Goal 2015 as well, includes goal number six, which is also related to the provision of clean water and sanitation till 2030 to every region of the world. The above discussion evident the need for safe, decentralized low-cost treatment technology for water disinfection as an urgent need in rural and remote areas to solve health-related issues. A number of conventional methods like Ultraviolet rays, ozonation, and chemical disinfection are being used to disinfect drinking water and even though the literature indicates, there are a number of deaths recorded due to the water-borne diseases. The paper discusses the widely utilized approaches with their pros and cons to identify the drawbacks in those systems. The literature based on the conventional disinfection methods indicates that the potential of DBP formation is more in Ultraviolet light disinfection than in chlorination. The chlorination is an extremely economical and extensively used disinfection method among the conventional decontamination methods with a unique property of having a residual effect. The available literature related to the chlorination is considerably more than this ozonation and UV. 
The reason can be the drawbacks of these treatments, and the high cost of UV and Ozone treatments due to which only developed countries incorporated few researches related to it.

Even though chlorination has advantages over UV and ozonation, Chlorine gas is a strong oxidizer and considered toxic. The literature also indicates that chlorination has some drawbacks related to storage, safety, a requirement of skilled supervision, and the formation of DBPs. Some incidences of accidental chlorine leakage and the consequences are discussed in the paper. Drinking-water systems using chlorine for disinfection should monitor continuously as the hazardous effects of chlorination affect human health due to the extra amount of residual chlorine beyond the standard limit. Therefore, there is a need to engender new technology that will be economically feasible, decentralized, affordable, and accessible to solve the problems associated with the current water treatment system. The paper also discusses the novel technologies which can overcome the drawbacks of the conventional methods. The novel disinfection technologies like Electro-chlorination, Deep-Ultraviolet light-emitting diodes technology (DUV-LEDs) with a water waveguide (WW) (50), Inductively Coupled Plasma System (51), Nanobubble Technologies (52), Bioanalytical approach (53) and Ultraviolet light-emitting diode reactors (UV-LEDs) are studied by few researchers. The literature study indicates that the DeepUltraviolet light-emitting diodes technology (DUV-LEDs) and Ultraviolet light-emitting diode reactor (UV-LEDs) technologies required more energy and cost for its experimentation and implementation. While the results of the Inductive Coupled Plasma System proposed that there is a need for further work to make the process serviceable by increasing the applied frequency for the elimination of pathogenic bacteria. The electro-chlorination process is a more convenient and highly efficient way for the production of germ-free water. Jung et al., 2007, concludes that the Electro-chlorination process reduces the formation of DBP's. From the available literature, it can be established that the electro decontamination practice is more operative than the chlorination process. The study of Electro-chlorination literature indicates the research related to these technologies is very much less and very rarely used in the real scenarios in developing countries to disinfect water. The studies to optimize the parameters influencing the maximum chlorine production during electro-chlorination are limited (63),(64),(67),(66).

From the systematic study of literature related to conventional and Novel drinking water disinfection techniques, it can be concluded that Electro-chlorination, is one of the suitable and economical alternatives for rural zones of the developing countries. Some researchers have tried few labscale models but not introduced it to deal with the real problems in developing countries. Therefore, more scope to study further related to the electro-chlorination technique by overcoming the gaps in the existing research that are clarified in the above literature and to make it possible to adapt a lab-scale model to pilot station which is really useful to the rural zones in developing countries.

\section{Ethical issue}

Authors are aware of, and comply with, best practice in publication ethics specifically with regard to authorship (avoidance of guest authorship), dual submission, manipulation of figures, competing interests and compliance with policies on research ethics. Authors adhere to publication requirements that submitted work is original and has not been published elsewhere in any language.

\section{Competing interests}

The authors declare that there is no conflict of interest that would prejudice the impartiality of this scientific work.

\section{Authors' contribution}

All authors of this study have a complete contribution for data collection, data analyses and manuscript writing.

\section{References}

1. Wright JA, Gundry S, Wright J, Conroy R. A systematic review of the health outcomes related to household water quality in developing countries household water quality in developing countries. 2004;(May 2014).

2. Preventing diarrhoea through better water, sanitation and hygiene.

3. Suthar S. Contaminated drinking water and rural health perspectives in Rajasthan, India: An overview of recent case studies. Environ Monit Assess. 2011;173(1-4):837-49.

4. Jiménez-Moleón MC, Gómez-Albores MA. Waterborne diseases in the state of Mexico, Mexico (2000-2005). J Water Health. 2011;9(1):200-7.

5. Nogueira G, Nakamura C V., Tognim MCB, Abreu Filho BA, Dias Filho BP. Microbiological quality of drinking water of urban and rural communities, Brazil. Rev Saude Publica. 2003;37(2):232-6.

6. Amrose S, Burt Z, Ray I. Safe Drinking Water for Low-Income Regions. Annu Rev Environ Resour. 2015;40(1):203-31.

7. Hossain MJ, Shimul EK, Jahan S. SAFE DRINKING WATER SCARCITY IN THE SOUTHWESTERN COASTAL REGION OF BANGLADESH: A SCENARIO OF SARANKHOLA UPAZILA , BAGERHAT DISTRICT SAFE DRINKING WATER SCARCITY IN THE SOUTHWESTERN COASTAL REGION OF BANGLADESH : A SCENARIO OF SARANKHOLA UPAZILA, BAGERHA. 2017;(October).

8. Bain R, Cronk R, Wright J, Yang H, Slaymaker T, Bartram J, et al. Fecal Contamination of Drinking-Water in Low- and MiddleIncome Countries: A Systematic Review and Meta-Analysis Introduction.

9. Li H, Zhu X, Ni J. Electrochimica Acta Comparison of electrochemical method with ozonation, chlorination and monochloramination in drinking water disinfection. Electrochim Acta [Internet]. 2011;56(27):9789-96. Available from: http://dx.doi.org/10.1016/j.electacta.2011.08.053

10. Hua W, Bennett ER, Letcher RJ. Ozone treatment and the depletion of detectable pharmaceuticals and atrazine herbicide in drinking water sourced from the upper Detroit River, Ontario, Canada. Water Res. 2006;40(12):2259-66.

11. Kim K, Hong W. Disinfection Characteristics of Waterborne Pathogenic Protozoa Giardia lamblia. 2001;95-9.

12. Shannon MA, Bohn PW, Elimelech M, Georgiadis JG, Marin BJ, Mayes AM. Science and technology for water purification in the coming decades. 2008;452(March):337-46.

13. Author E. Simultaneous control of microorganisms and disinfection by- products by sequential chlorination (Article). 2007;20(2).

14. Ghernaout D, Alghamdi A, Ghernaout B. Microorganisms' Killing: Chemical Disinfection vs. Electrodisinfection. Electrodisinfection Appl Eng [Internet]. 2019;3(1):13-9. Available from: http://www.sciencepublishinggroup.com/j/ae

15. Chalmers TC, Angelillo IF. Chlorination, Chlorination Byproducts, and. 1992;955-63.

16. Addendum F, Third TO. Guidelines for Drinking-water Quality. 1.

17. Domènech L. Rethinking water management : From centralised to decentralised water supply and sanitation models Rethinking water management : From centralised to decentralised water supply and sanitation models. 2015;(December)

18. Obermann I, Sattler K. Comparison of centralized, semicentralized and decentralized sanitation systems. :159-67.

19. WHO/UNICEF. Progress on Sanitation and Drinking water.methodology 2015 update \& sdg baselines. 2018;(March 2017):1-23.

20. Johnston RB. Arsenic and the 2030 Agenda for sustainable development. Arsen Res Glob Sustain - Proc 6th Int Congr Arsen Environ AS 2016. 2016;12-4.

21. Water D. Progress on Drinking Water, Sanitation and Hygiene. 
2017.

22. Lawrence J, Cappelli FP. Ozone in drinking water treatment: A review. Sci Total Environ. 1977;7(2):99-108.

23. Wnlfe RL, Po LACA. Ultraviolet disinfixtion of potable water. $1990 ; 24$.

24. Plummer JD, Edzwald JK. Effect of ozone on disinfection byproduct formation of algae. Water Sci Technol [Internet]. 1998;37(2):49-55. Available from: http://dx.doi.org/10.1016/S0273-1223(98)00009-2

25. Mao Y, Guo D, Yao W, Wang X, Yang H, Xie YF, et al. Effects of conventional ozonation and electro-peroxone pretreatment of surface water on disinfection by-product formation during subsequent chlorination. Water Res [Internet]. 2018;130:322-32. Available from: https://doi.org/10.1016/j.watres.2017.12.019

26. van der Merwe W, Beukes JP, van Zyl PG. Cr(VI) formation during ozonation of $\mathrm{Cr}$-containing materials in aqueous suspension - Implications for water treatment. Water SA. 2012;38(4):505-10.

27. Chien IC, Wu SP, Ke HC, Lo SL, Tung HH. Comparing ozonation and biofiltration treatment of source water with high cyanobacteria-derived organic matter: The case of a water treatment plant followed by a small-scale water distribution system. Int J Environ Res Public Health. 2018;15(12).

28. Cho M, Chung H, Yoon J. Disinfection of Water Containing Natural Organic Matter by Using Ozone-Initiated Radical Reactions. 2003;69(4):2284-91.

29. Schlichter B, Mavrov V, Chmiel H. Study of a hybrid process combining ozonation and microfiltration/ultrafiltration for drinking water production from surface water. Desalination. 2004;168(1-3):307-17.

30. Bonacquisti TP. A drinking water utility's perspective on bromide, bromate, and ozonation. Toxicology. 2006;221(2-3):145-8.

31. Liu W, Cheung LM, Yang X, Shang C. THM, HAA and CNCl formation from UV irradiation and chlor(am)ination of selected organic waters. Water Res. 2006;40(10):2033-43.

32. Lu N, Gao NY, Deng Y, Li QS. Nitrite formation during low pressure ultraviolet lamp irradiation of nitrate. Water Sci Technol. 2009;60(6):1393-400.

33. Choi Y, Choi Y june. The effects of UV disinfection on drinking water quality in distribution systems. Water Res [Internet]. 2010;44(1):115-22. Available from: http://dx.doi.org/10.1016/j.watres.2009.09.011

34. American Water Works Association (AWWA). 2012;101(3):5960 .

35. Deng L, Huang CH, Wang YL. Effects of combined UV and chlorine treatment on the formation of trichloronitromethane from amine precursors. Environ Sci Technol. 2014;48(5):2697-705.

36. Wang D, Bolton JR, Andrews SA, Hofmann R. Science of the Total Environment Formation of disinfection by-products in the ultraviolet / chlorine advanced oxidation process. Sci Total Environ [Internet]. 2015;518-519:49-57. Available from: http://dx.doi.org/10.1016/j.scitotenv.2015.02.094

37. Mcdonald K, Clevenger T, Curry R, Golden J. Ultraviolet Light Technologies for Water Treatment Ken McDonald, Tom Clevenger and Randy. :299-311.

38. Baxter G. Chlorine disinfection: The industry standard. Water Supply. 1995;13(2):183-93.

39. Taflin C. A low-cost solution to rural water disinfection: The development of an effective chlorinator. IEEE Eng Med Biol Mag. 2006;25(3):36-7.

40. Boulay $\mathrm{N}$, Edwards M. ROLE OF TEMPERATURE CHLORINE, AND ORGANIC MATTER IN COPPER CORROSION BY-PRODUCT RELEASE IN SOFT WATER. 2001;35(3):683-90.

41. Taylor P, Ghernaout D, Ghernaout B. Desalination and Water Treatment From chemical disinfection to electrodisinfection: The obligatory itinerary? From chemical disinfection to electrodisinfection: The obligatory itinerary? 2012;(December 2014):37-41

42. Wilson RE, Centre NO, Stoianov I, Hare DO. Continuous Chlorine Detection in Drinking Water and a Review of New Detection Methods. 2018;(January).

43. Chlorine leak on Mumbai Port Trust.

44. Falakh F, Setiani O. Hazard Identification and Risk Assessment in Water Treatment Plant considering Environmental Health and Safety Practice. 2018;06011:1-5.
45. Hrudey SE. Chlorination disinfection by-products, public health risk tradeoffs and me. Water Res [Internet]. 2009;43(8):2057-92. Available from: http://dx.doi.org/10.1016/j.watres.2009.02.011

46. Li X, Mitch WA. Drinking Water Disinfection Byproducts ( DBPs ) and Human Health Effects: Multidisciplinary Challenges and Opportunities. 2017;

47. Pressman JG, Speth TF, Miltner RJ, Narotsky MG, Hunter ES, Rice GE, et al. Concentration , Chlorination , and Chemical Analysis of Drinking Water for Disinfection Byproduct Mixtures Health Effects Research: U . S . EPA's Four Lab Study. 2010;44(19):7184-92.

48. Ghernaout D. International Journal of Advanced and Applied Sciences Disinfection and DBPs removal in drinking water treatment : A perspective for a green technology. 2018;5(2):10817.

49. Saha J, Gupta SK. Application of response surface methodology for optimization of an onsite electro-chlorinator for drinking water treatment. 2018;

50. Matsumoto T, Tatsuno I, Hasegawa T. Instantaneous water purification by deep ultraviolet light in water waveguide: Escherichia coli bacteria disinfection. Water (Switzerland). 2019;11(5).

51. Desmiarti R, Hazmi A, Martynis M, Sutopo UM, Li F. Behavior of microorganisms in drinking water treatment by inductively coupled plasma system: Case study in ground water. AIP Conf Proc. 2018;1931.

52. Atkinson AJ, Apul OG, Schneider O, Garcia-Segura S, Westerhoff P. Nanobubble Technologies Offer Opportunities to Improve Water Treatment. Acc Chem Res. 2019;(Table 1).

53. Lundqvist J, Andersson A, Johannisson A, Lavonen E, Mandava $\mathrm{G}$, Kylin $\mathrm{H}$, et al. Innovative drinking water treatment techniques reduce the disinfection-induced oxidative stress and genotoxic activity. Water Res. 2019;155:182-92.

54. Disinfection UFD. Application of Ultraviolet Light-Emitting Diodes. 2019;

55. Riyanto, Agustiningsih WA. Electrochemical disinfection of coliform and Escherichia coli for drinking water treatment by electrolysis method using carbon as an electrode. IOP Conf Ser Mater Sci Eng. 2018;349(1).

56. Chen X, Wang Y, Li W, Ding Z, Lu Y, Ding J, et al. Anti-bacterial performance, disinfection by-products control and optimization strategy in distributed potable water supply using electrolysis. J Clean Prod [Internet]. 2020;265:121810. Available from: https://doi.org/10.1016/j.jclepro.2020.121810

57. Eugene D, Suffet IH. Electrochemical removal of bromide and reduction of THM formation potential in drinking water. 2002;36:4902-6.

58. Jung YJ, Oh BS, Kang JW, Page MA, Phillips MJ, Marin BJ Control of disinfection and halogenated disinfection byproducts by the electrochemical process. 2007;(Figure 1):213-9.

59. Ghernaout D, Ghernaout B. From chemical disinfection to electrodisinfection: The obligatory itinerary? 2010;

60. Mezule L, Reimanis M, Krumplevska V, Ozolins J, Juhna T. Comparing electrochemical disinfection with chlorination for inactivation of bacterial spores in drinking water. 2014;158-64.

61. Kraft BA. Electrochemical Water Disinfection: A Short Review. 2008;(3):177-85.

62. Wang Y, Claeys L, Ha D Van Der, Verstraete W, Boon N. Effects of chemically and electrochemically dosed chlorine on Escherichia coli and Legionella beliardensis assessed by flow cytometry. 2010;331-41.

63. Khelifa A, Moulay S, Hannane F, Benslimene S, Hecini M. Application of an experimental design method to study the performance of electrochlorination cells. 2004;160:4-8.

64. Ghalwa NA, Tamos H, Elaskalni M, Rhman A, Agha E. Generation of sodium hypochlorite $(\mathrm{NaOCl})$ from sodium chloride solution using $\mathrm{C} / \mathrm{PbO} 2$ and $\mathrm{Pb} / \mathrm{PbO} 2$ electrodes. 2012;19(6):561-6.

65. Choi J, Gyu C, Yoon J. Application of an electrochemical chlorinegeneration system combined with solar energy as appropriate technology for water disinfection. 2013;(October 2012):124-8.

66. Saha J, Gupta SK. A novel electro-chlorinator using low cost graphite electrode for drinking water disinfection. 2017;

67. Choi J, Shim S, Yoon J. Design and operating parameters affecting an electrochlorination system. J Ind Eng Chem. 2013;19(1):215- 
9.

68. Max Roser, Our World In Data,

https://ourworldindata.org/search?q=drinking+water (Accessed on 20 th May 2020)

69. Max Roser, Our World In Data,

https://ourworldindata.org/grapher/urban-improved-water-accessvs-rural-water-access. (Accessed on 20 th May 2020)

70. Elsevier Scopus, Scopus, https://www.scopus.com (Accessed on 17th May 2020)

71. Clarivate, Web of Science, https://www.webofscience.com (Accessed on 17th May 2020)

72. The Times Group - e paper, News from TOI, The Times of India, https://timesofindia.indiatimes.com/india/Chlorine-leak-atJamshedpur-plant-leaves-200-ill/articleshow/3078258.cms, (Acessed on 20 th April 2020).

73. Lindsey Blest, Lancaster Online, e-newspaper,

https://lancasteronline.com/news/local/man-suffers-minor-injuryfrom-chlorine-exposure-in-leak-at/article_8d601276-d06f-11e8a3f9-33494d0dfc3d.html, (Acessed on 20 th April 2020). 